Volume and Issues Obtainable at Center for Sustainability Research and Consultancy

Journal of Business and Social Review in Emerging Economies

ISSN: 2519-089X (E): 2519-0326

Volume 6: No. 4, December 2020

Journal homepage: www.publishing.globalcsrc.org/jbsee

\title{
A Descriptive Analysis of Compensation Offerings and its Impact on Turnover Intentions of Educational Managers of Punjab
}

\author{
${ }^{1}$ Majid Ali, ${ }^{2}$ Muhammad Ramzan, ${ }^{3}$ Rizwan Qaiser Danish \\ ${ }^{1}$ Assistant Professor, Hailey College of Commerce, University of the Punjab, Lahore, Pakistan, \\ majid.hcc@pu.edu.pk \\ ${ }^{2}$ Assistant Professor, Hailey College of Commerce, University of the Punjab, Lahore, Pakistan, \\ wadraha1@gmail.com \\ ${ }^{3}$ Associate Professor, Institute of Business Administration, University of the Punjab, Lahore, Pakistan, \\ rqdanish@hcc.edu.pk
}

\begin{tabular}{l}
\hline ARTICLE DETAILS \\
\hline History \\
Revised format: November \\
2020 \\
Available Online: December \\
2020 \\
\hline Keywords \\
compensation, education, \\
offerings, intention to leave.
\end{tabular}

\section{JEL Classification}

M10, M11

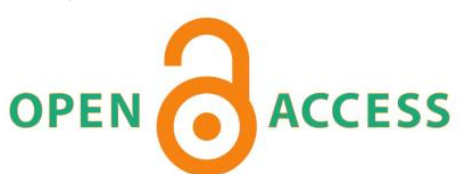

ABSTRACT

This research is aimed at investigating compensation offerings at various levels and its impact on the turnover intentions of employees in educational sector of Punjab. It specifically addressed the issue how different compensation offerings (for example pay, bonus, medical facility, housing etc) effects on intention to quit from the organisation. The research has focused on gauging the impact of the compensation package on the educational managers' intention to quit, i. e. turnover, and to know to what extent degree of impact of each constituent of the compensation package has on their intention to leave the organization. This study has provided implications for policy makers in different organisations related to education particularly in Pakistani context.

(C) 2020 Center for Sustainability Research and Consultancy Pakistan under a Creative Commons Attribution-NonCommercial-ShareAlike

4.0

Corresponding author's email address: majid.hcc@ @u.edu.pk

Recommended citation: Ali, M., Ramzan, M. \& Danish, R. Q. (2020). A Descriptive Analysis of Compensation Offerings and its Impact on Turnover Intentions of Educational Managers of Punjab. Journal of Business and Social Review in Emerging Economies, 6(4), 1631-1651

\section{Introduction}

Educational sector of Pakistan is typically characterised with high turnover and teaching and nonteaching staff switch their jobs rapidly. In this way, hiring and retaining talented employees incur a huge cost. In a study by Steers, the research undertaken to understand the offerings of compensation by a company and its various elements and demonstrates that there exists a bond among the rewards a company compromises and persons individuals which are engrossed to the compensation into working for the organization, and incumbents which wanted to remain the part of business (Steers, 1991). The flourishing economy of Pakistan with a greatest extended economic expansion, specifically with the foundation of CPEC, a younger and mid-career workforce that are not old work force is increasing on regular basis and it is also evident how short joblessness is putting burden on educational industry wages while more and more PhDs and MPhils are saturating the market. Organizations and institutions in this important sector are reacting with heaps of new customized and choice based employee reward packages and benefit contributions not characteristically available from other type of firms. As a result, employees are very keen in retorting with thoughts around in which way continuum of new liaison of employee and employer must graft in the new-fangled economic conditions. 


\section{Significance of the Study}

From a standpoint of theory, this study is an effort to provide suggestion of the financial and non financial elements of compensation that are considered of utmost prominence to educational managers. The recent bulk of scholar's work on this area of educational management, endeavors to help further in understanding of rewards, both related financial and nonfinancial, along with their intentions to leave their jobs. This investigation also anticipates contributing to the scant studies by presenting indication of the mark to which management benefit bundles, as a whole, have an encouragement on intentions to halt with the group of universal managers. Finally, two "open ended questions" have been focused on establishing "what is the most important factor influencing a general manager's decision to stay with the company", and "what is the most important factor influencing their decision to leave". As per pragmatic approach, this research is to chart new boundaries to escort managers yearning to advance their retaining and diminish their turnover as an emblem of the useful or tolerant compensation strategies. These types of different financial and non-financial compensation plans will provide and reduce turnover.

In recent times the more focus is being paid on the employees how well they are performing in their organizations. How well an organization gears its policies and programs regarding reward system and achieves its strategic intent in terms of its mission and vision is of paramount concern. Managers are becoming increasingly aware in both private and public organizations that using an apt compensation plan a critical source of competitive advantage often comes from a suitable system of attracting and managing the organizations human resources. Hence following are the research questions and objectives of the study.

\section{Research Objectives}

1. To investigate the existing management reward or compensation practices of the educational managers

2. To find the relationship between compensation practices and turnover intentions in teaching and nonteaching managerial staff.

3. To identify the differences in various managerial level in compensation and turnover intentions.

\section{Research Questions}

The following basic research questions of this study have been described below:

1. Are the employes turnover intention decrease by the compensation plan for educational managers?

2. Among compensation essentials which in turn, as identified by different educational managers, effect turnover intentions?

\section{Literature Review \\ 5.1 Compensation}

Lawler (1981) explained that total or whole compensation composed of all the benefits in cash or financial forms plus other fringe benefits which are received $b$ employees from a company during a time is called compensation. Dibble (1999) expands the definition of earnings, "it is money even when we do not use the word" and further elaborates by stating that "a benefit like employee development, even though not necessarily viewed by the employee as compensation, is a substitute for money and a major cost for employers". In today's era, the rewards offered to employees has extended both in terms of category and quantity. Normally, a meeting is conducted after a fixed term usually one year and compensation plan is offered to managers along with annual bonus or increments based on performance considering goals for revenues and expenses of the company (Muller, 1999). In broad, compensation is categorized among two types among which one is monetary and second is non-monetary, however as the time has passed new idea of cafeteria compensation has been devised in which employees are offered a long range of benefits from which he can take whatever he wants within his limitations. Moreover, employees that have knowledge skills and abilities at their peak, they are in a better position to negotiate with the employer like a sports man. The following lists will give an overview of some of the categories and types of bonuses:

\section{"Base Pay"}

- "Salary and wages- for being at work" 
"Increases for Demonstrating New Skills"

- "Competency pay"

- "Skill based pay"

- "Job progression"

"Increases for Results"

- "Incentive"

- "Commission"

- "Gainsharing"

- "Merit increase"

"Pay For Working More Hours"

- "Overtime"

- "Premium pay"

"Increases not Dependent on Anything Else"

- "Cost of living adjustment- COLA"

- "General Increase"

"Increase Based on the Organizations Financial Success"

- "Profit sharing"

- "Bonus"

"Other Forms of Increases"

- "Promotional increase"

- "Market adjustment"

"Short term incentives

- Retention bonus

- Signing bonus

- Referral bonus

- Guaranteed annual bonus

- Gainsharing

- Cash incentive programs

- Vacation awards

Long term incentives

- Stock options

- Employee stock ownership

- IPO equity

- Restrictive stock

- Manager bonus plan

- Ownership stake

- 401K plan

- Retirement plan

- Deferred compensation- 3 years or longer"

\subsection{Turnover}

Turnover has been defined by Mobley (1982) as "the cessation of membership in an organization by an individual who received monetary compensation from the organization". According to Wasmuth and Davis (1983), there are various schemes for categorizing employee turnover. Specifically, for this study the contrast of deliberate versus unintentional will be used since the research will focus on the employee's intention to turnover. Voluntary turnover is the choice of employee how he wants to quit from his own will and by choice, whereas quite opposite to it is involuntary turnover which is based on the option of organization due to any reason including retirement and death (Mobley, 1982).

\subsection{Intention to Turnover}

In theory, a good predictor of future behavior must be a person's behavioral intentions according to multiple research studies offered by Mobley (1982). In the previous study including intention to quit seven variables were studied as a predictor for turnover by Mobley, he concluded that when all variables were combined, "only intention to quit was significantly related to turnover". Additionally, determined 
through the other study, that intentions to leave served as a "summary variable" encompassing many other variables that were associated to turnover. The assessment by Mobley was, "intentions are the best predictors of turnover". Intent to quit was used as a substitute for actual turnover by McFillen, Riegel and Enz because the capability to quit the job depend upon whether the employee can quit.

According to Woods (1999), the relationship changed through the process of reengineering, downsizing and reorganization when businesses decided to break the "psychological contracts" they had long held with employees, which gave employees a sense of security, in the late 1980's and 90's. Today we are "employed at will" Because employees are "temporary", in the sense that mostly employees do not holds a job for whole life; Despite the certainties of the new economy still there are avoidable reasons for turnover and ways to decrease it.

Many reasons of turnover may be:

- Pay

- "Treatment by superiors"

- "Amount of work hours"

- "Job pressure"

- "Scheduling of hours - frustration with the chain"

- "Training program - slow promotions"

- "Fringe benefit packageperformance expectations- poor job performance"

- "Attractive opportunity in another line of work"

- "Working manager concept- need for a new challenge- type of work required"

- "Physical demands of job"

- "Inability to live up to chain store managers image"

- "Inability to handle job"

- "Desire to get out of education business"

- "Desire to find work in another geographic area" 
According to Lazear (1999) Turnover is less likely among high wage, high performing workers. Roseman states (1981), that for "more money" peoples quit the companies and "there is no question that pay rates can influence turnover however, managers generally overestimate the significance of pay". It is sure that pay is significant, but "there are many other issues, other than pay, that effect intention to turnover. In any company, employees can compare their pay with individuals or groups internal and external to the organization. Both internal and external inequity can have dire consequences for the firm", though the outcomes of external equity such as turnover are the most threatening according to Lawler (1981).

In the recent years another issue is planned turnover which has gained more attention. According to Lawler "not all turnover is detrimental to an organizations ability to be effective (Lawler, 1987). From losing poor performers and the inflow of "new blood" organization can benefit. When the replacement costs are negligible then it could be cost effective to agree to take a higher rate of turnover for keeping salaries repressed, and it may be the situation with unqualified labor. In additionally, when a project has a limited lifetime and the need for the employees linked with the project will come to an end" then use of planned turnover is effective.

\section{Method}

Data was collected through self-administered questionnaire including open ended questions from sample and population which was appropriate for this study. Unit of analysis was individual and there was minimal interference of researcher. As there were four different levels of employees, so multilevel data was analyzed to see if there is any difference among different levels.

The questionnaire with major focus on demographic variables and compensation types or offerings was distributed among the academic staff with some managerial responsibilities. Their turnover intentions were measured by one global question as whether they want to leave their job or not. We consider every person having 2 or more people under him or her to manage with. Overall 600 questionnaires were distributed among which 560 were returned filled. Among these 16 were discarded due to missing data or left-over page thus making useable response $91 \%$.

The respondents were questioned on five point Likert scale with anchors "Not at all influential", "Slightly Influential" "Moderately Influential" "Very Influential" and "Extremely Influential" and we analyzed it on major demographic variables, analysis of variance and correlation. The results are described in the next section.

\section{Result and Analysis}

Data has been analyzed through SPSS software for in depth analysis. Frequencies, mean, standard deviation, correlation, regression, and ANOVA were run for descriptive analysis and multilevel differences.

\subsection{Descriptive Statistics}

\subsubsection{Basic Salary}

Table 1. Salary of Respondents

\begin{tabular}{|l|l|l|l|l|}
\hline & Frequency & Percent & Valid Percent & Cumulative Percent \\
\hline Not at all influential & 39 & 7.1 & 7.1 & 7.1 \\
\hline Slightly influential & 59 & 10.8 & 10.8 & 17.9 \\
\hline Moderately influential & 136 & 24.9 & 24.9 & 42.9 \\
\hline Very influential & 181 & 33.2 & 33.2 & 76.0 \\
\hline Extremely influential & 131 & 24.0 & 24.0 & 100.0 \\
\hline Total & $\mathbf{5 4 6}$ & $\mathbf{1 0 0 . 0}$ & $\mathbf{1 0 0 . 0}$ & \\
\hline
\end{tabular}


Table 1 explains that out of total 546 respondents the basic salary of 39 respondents was "Not at all influential", 59 respondents had "Slightly Influential" salary, 136 respondents had "Moderately Influential" salary, 181 respondents has "Very Influential" salary and 131 respondents had "Extremely Influential" salary with a percentage of $7.1 \%, 10.8 \%, 24.9 \%, 33.2 \%$ and $24.0 \%$ making it cumulative of $100.0 \%$.

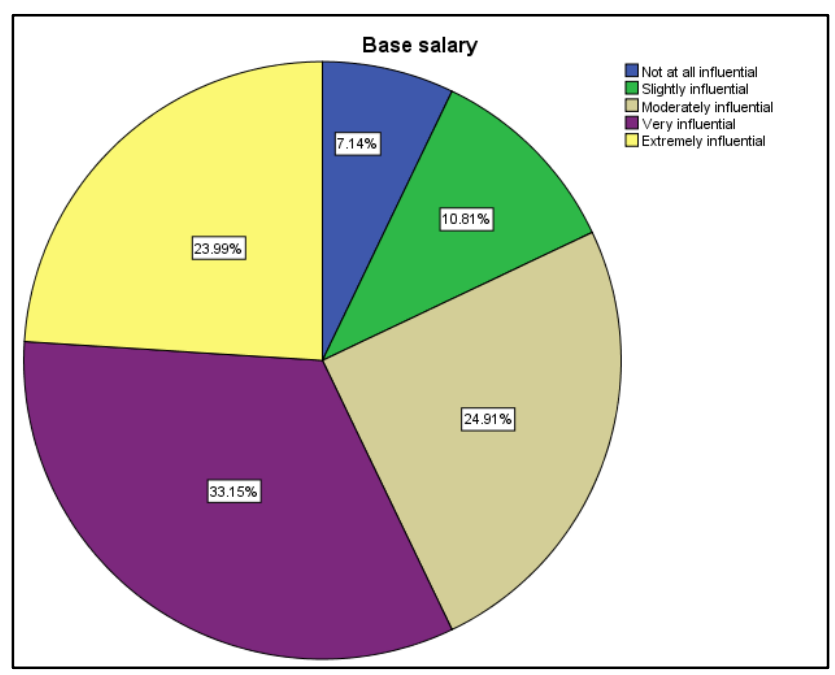

\subsection{Community Association/ Location}

Table 2. Location of Respondents

\begin{tabular}{|l|l|l|l|l|}
\hline & Frequency & Percent & Valid Percent & Cumulative Percent \\
\hline Not at all influential & 39 & 7.1 & 7.1 & 7.1 \\
\hline Slightly influential & 76 & 13.9 & 13.9 & 21.1 \\
\hline Moderately influential & 135 & 24.7 & 24.7 & 45.8 \\
\hline Very influential & 202 & 37.0 & 37.0 & 82.8 \\
\hline Extremely influential & 94 & 17.2 & 17.2 & 100.0 \\
\hline Total & $\mathbf{5 4 6}$ & $\mathbf{1 0 0 . 0}$ & $\mathbf{1 0 0 . 0}$ & \\
\hline
\end{tabular}

Table 2 explains that out of total 546 respondents the location or community association of 39 respondents was "Not at all influential", 76 respondents had "Slightly Influential" salary, 135 respondents had "Moderately Influential" salary, 202 respondents has "Very Influential" salary and 94 respondents had "Extremely Influential" salary with a percentage of $7.1 \%, 13.9 \%, 24.7 \%, 37.0 \%$ and $17.2 \%$ making it cumulative of $100.0 \%$. 


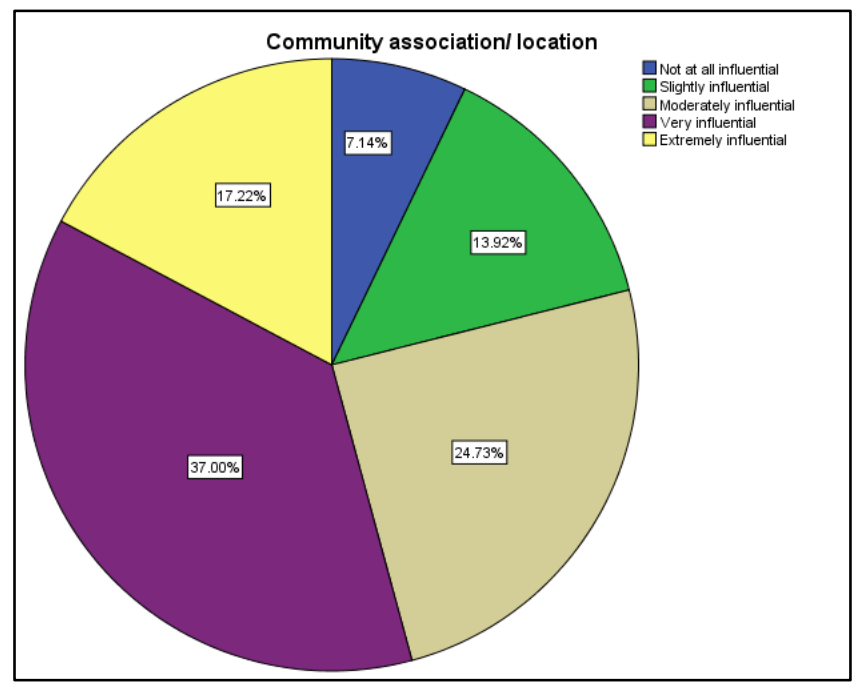

\subsection{Deferred compensation/ end of contract cash out}

Table 3. Deferred Compensation of Respondents

\begin{tabular}{|l|l|l|l|l|}
\hline & Frequency & Percent & Valid Percent & Cumulative Percent \\
\hline Not at all influential & 58 & 10.6 & 10.6 & 10.6 \\
\hline Slightly influential & 148 & 27.1 & 27.1 & 37.7 \\
\hline Moderately influential & 137 & 25.1 & 25.1 & 62.8 \\
\hline Very influential & 147 & 26.9 & 26.9 & 89.7 \\
\hline Extremely influential & 56 & 10.3 & 10.3 & 100.0 \\
\hline Total & $\mathbf{5 4 6}$ & $\mathbf{1 0 0 . 0}$ & $\mathbf{1 0 0 . 0}$ & \\
\hline
\end{tabular}

Table 3 explains that out of total 546 respondents the deferred compensation of 58 respondents was "Not at all influential", 148 respondents had "Slightly Influential" salary, 137 respondents had "Moderately Influential" salary, 147 respondents has "Very Influential" salary and 56 respondents had "Extremely Influential" salary with a percentage of $10.6 \%, 27.1 \%, 25.1 \%, 26.29$ and $10.3 \%$ making it cumulative of $100.0 \%$.

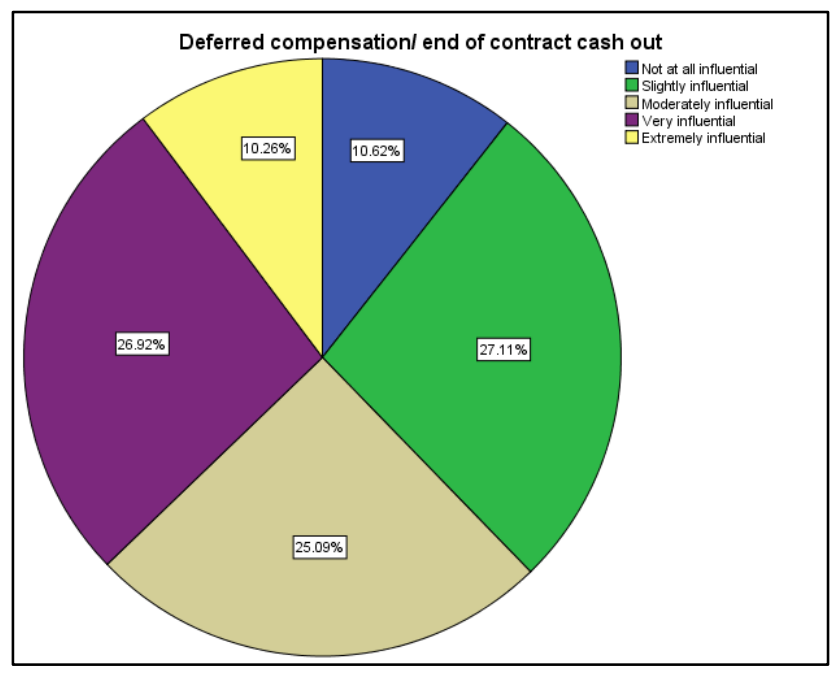




\subsection{Job Autonomy}

Table 4. Job Autonomy of Respondents

\begin{tabular}{|l|l|l|l|l|}
\hline & Frequency & Percent & Valid Percent & Cumulative Percent \\
\hline Not at all influential & 32 & 5.9 & 5.9 & 5.9 \\
\hline Slightly influential & 71 & 13.0 & 13.0 & 18.9 \\
\hline Moderately influential & 121 & 22.2 & 22.2 & 41.0 \\
\hline Very influential & 239 & 43.8 & 43.8 & 84.8 \\
\hline Extremely influential & 83 & 15.2 & 15.2 & 100.0 \\
\hline Total & $\mathbf{5 4 6}$ & $\mathbf{1 0 0 . 0}$ & $\mathbf{1 0 0 . 0}$ & \\
\hline
\end{tabular}

Table 4.0 explains that out of total 546 respondents the job autonomy of 32 respondents was "Not at all influential", 71 respondents had "Slightly Influential" salary, 121 respondents had "Moderately Influential" salary, 239 respondents has "Very Influential" salary and 83 respondents had "Extremely Influential" salary with a percentage of $5.9 \%, 13.0 \%, 22.2 \%, 43.8$ and $15.2 \%$ making it cumulative of $100.0 \%$.

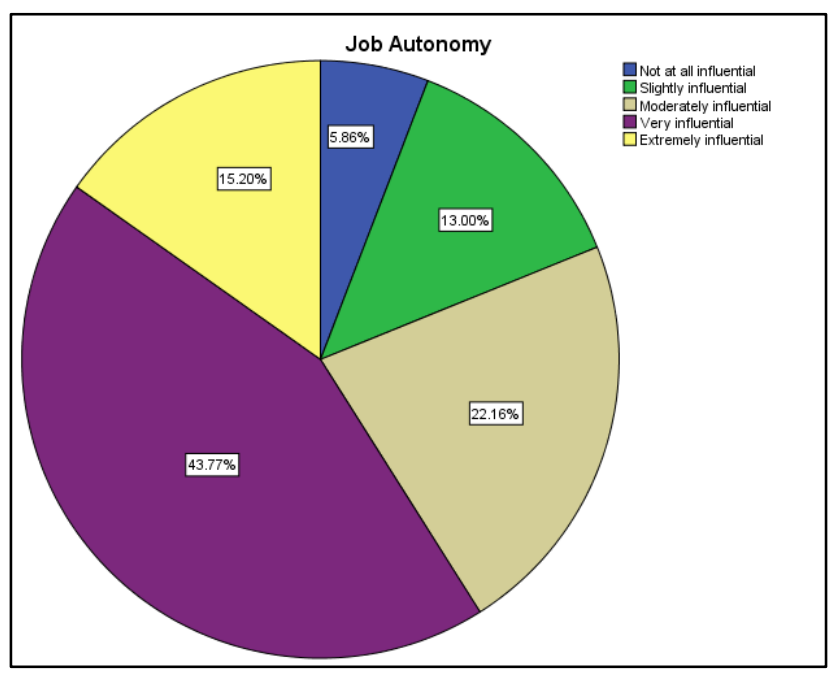

\subsection{Job Responsibility}

Table 5 Job Autonomy of Respondents

\begin{tabular}{|l|l|l|l|l|}
\hline & Frequency & Percent & Valid Percent & Cumulative Percent \\
\hline Not at all influential & 45 & 8.2 & 8.2 & 8.2 \\
\hline Slightly influential & 68 & 12.5 & 12.5 & 20.7 \\
\hline Moderately influential & 112 & 20.5 & 20.5 & 41.2 \\
\hline Very influential & 193 & 35.3 & 35.3 & 76.6 \\
\hline Extremely influential & 128 & 23.4 & 23.4 & 100.0 \\
\hline Total & $\mathbf{5 4 6}$ & $\mathbf{1 0 0 . 0}$ & $\mathbf{1 0 0 . 0}$ & \\
\hline
\end{tabular}

Table 5 explains that out of total 546 respondents the job responsibility of 45 respondents was "Not at all influential", 68 respondents had "Slightly Influential" salary, 112 respondents had "Moderately Influential" salary, 193 respondents has "Very Influential" salary and 128 respondents had "Extremely Influential" salary with a percentage of $8.2 \%, 12.5 \%, 20.5 \%, 35.3$ and $23.4 \%$ making it cumulative of $100.0 \%$. 


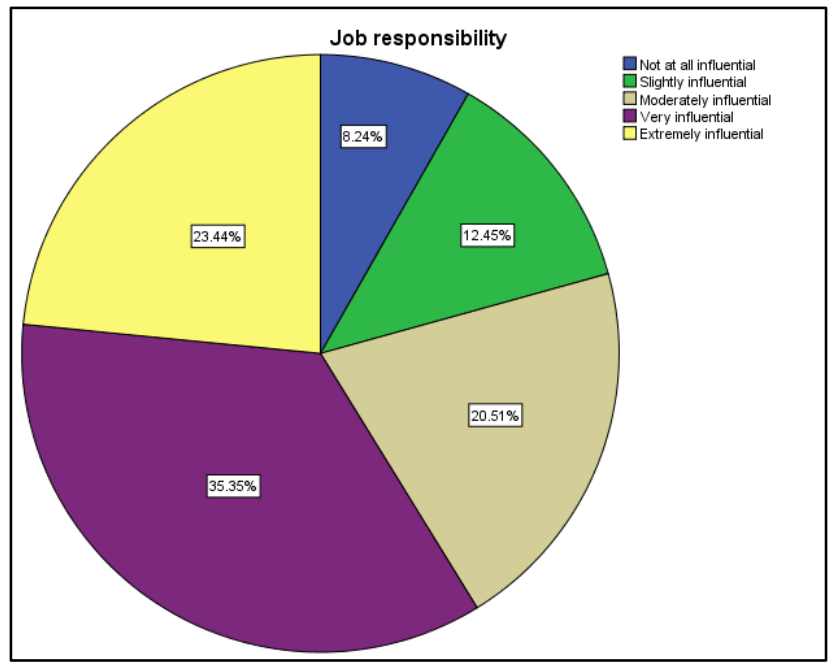

\subsection{Medical, Dental, Life Insurance}

Table 6 Job Medical, Dental and Life Insurance of Respondents

\begin{tabular}{|l|l|l|l|l|}
\hline & Frequency & Percent & Valid Percent & Cumulative Percent \\
\hline Not at all influential & 27 & 4.9 & 4.9 & 4.9 \\
\hline Slightly influential & 60 & 11.0 & 11.0 & 15.9 \\
\hline Moderately influential & 138 & 25.3 & 25.3 & 41.2 \\
\hline Very influential & 214 & 39.2 & 39.2 & 80.4 \\
\hline Extremely influential & 107 & 19.6 & 19.6 & 100.0 \\
\hline Total & $\mathbf{5 4 6}$ & $\mathbf{1 0 0 . 0}$ & $\mathbf{1 0 0 . 0}$ & \\
\hline
\end{tabular}

Table 6 explains that out of total 546 respondents the medical dental and life insurance of 27 respondents was "Not at all influential", 60 respondents had "Slightly Influential" salary, 138 respondents had "Moderately Influential" salary, 214 respondents has "Very Influential" salary and 107 respondents had "Extremely Influential" salary with a percentage of 4.9\%, 11.0\%, 25.3\%, 39.2 and $19.6 \%$ making it cumulative of $100.0 \%$.

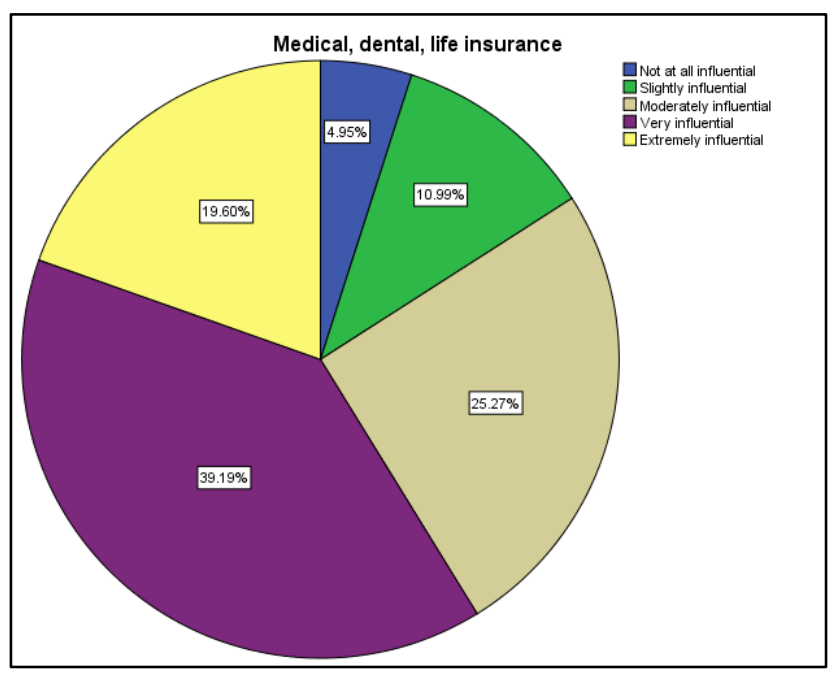




\subsection{Ownership Stake/ Equity Interest}

Table 7 Ownership of Respondents

\begin{tabular}{|l|l|l|l|l|}
\hline & Frequency & Percent & Valid Percent & Cumulative Percent \\
\hline Not at all influential & 38 & 7.0 & 7.0 & 7.0 \\
\hline Slightly influential & 56 & 10.3 & 10.3 & 17.2 \\
\hline Moderately influential & 172 & 31.5 & 31.5 & 48.7 \\
\hline Very influential & 196 & 35.9 & 35.9 & 84.6 \\
\hline Extremely influential & 84 & 15.4 & 15.4 & 100.0 \\
\hline Total & $\mathbf{5 4 6}$ & $\mathbf{1 0 0 . 0}$ & $\mathbf{1 0 0 . 0}$ & \\
\hline
\end{tabular}

Table 7 explains that out of total 546 respondents the ownership of 38 respondents was "Not at all influential", 56 respondents had "Slightly Influential" salary, 172 respondents had "Moderately Influential" salary, 196 respondents has "Very Influential" salary and 84 respondents had "Extremely Influential" salary with a percentage of $7.0 \%, 10.3 \%, 31.5 \%, 35.9 \%$ and $15.4 \%$ making it cumulative of $100.0 \%$.

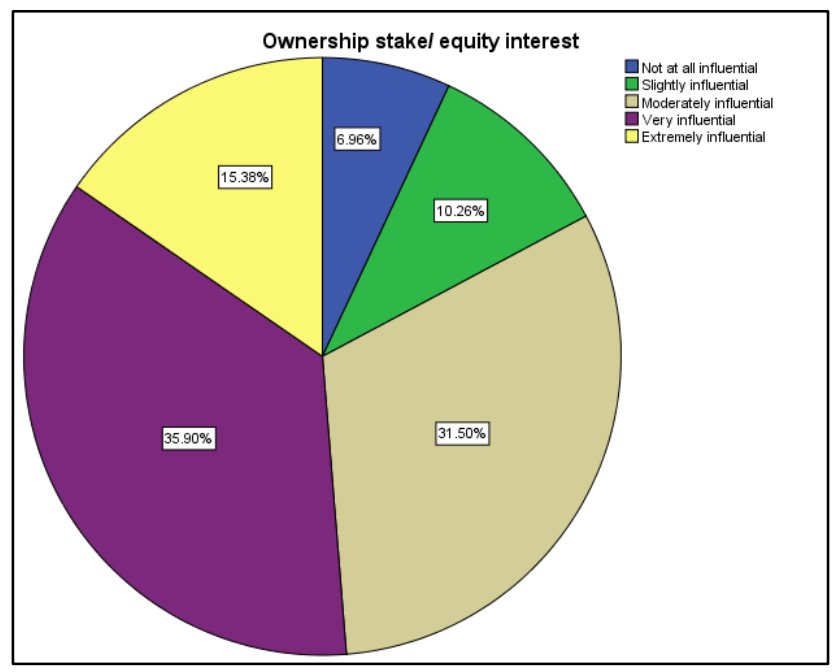

\subsection{Performance Bonus}

Table 8 Performance Bonus of Respondents

\begin{tabular}{|l|l|l|l|l|}
\hline & Frequency & Percent & Valid Percent & Cumulative Percent \\
\hline Not at all influential & 30 & 5.5 & 5.5 & 5.5 \\
\hline Slightly influential & 88 & 16.1 & 16.1 & 21.6 \\
\hline Moderately influential & 140 & 25.6 & 25.6 & 47.3 \\
\hline Very influential & 204 & 37.4 & 37.4 & 84.6 \\
\hline Extremely influential & 84 & 15.4 & 15.4 & 100.0 \\
\hline Total & $\mathbf{5 4 6}$ & $\mathbf{1 0 0 . 0}$ & $\mathbf{1 0 0 . 0}$ & \\
\hline
\end{tabular}

Table 8 explains that out of total 546 respondents the performance bonus of 30 respondents was "Not at all influential", 88 respondents had "Slightly Influential" salary, 140 respondents had "Moderately Influential" salary, 204 respondents has "Very Influential" salary and 84 respondents had "Extremely Influential" salary with a percentage of 5.5\%, 16.1\%, 25.6\%, 37.4\% and 15.4\% making it cumulative of $100.0 \%$. 


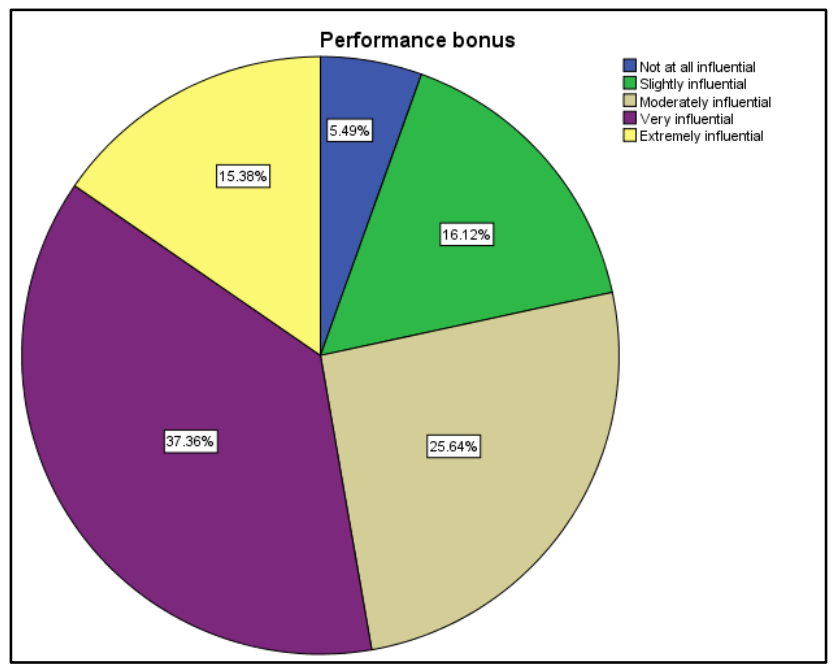

\subsection{Quality of Working Conditions}

Table 9 Quality of working conditions of Respondents

\begin{tabular}{|l|l|l|l|l|}
\hline & Frequency & Percent & Valid Percent & Cumulative Percent \\
\hline Not at all influential & 21 & 3.8 & 3.8 & 3.8 \\
\hline Slightly influential & 37 & 6.8 & 6.8 & 10.6 \\
\hline Moderately influential & 112 & 20.5 & 20.5 & 31.1 \\
\hline Very influential & 247 & 45.2 & 45.2 & 76.4 \\
\hline Extremely influential & 129 & 23.6 & 23.6 & 100.0 \\
\hline Total & $\mathbf{5 4 6}$ & $\mathbf{1 0 0 . 0}$ & $\mathbf{1 0 0 . 0}$ & \\
\hline
\end{tabular}

Table 9 explains that out of total 546 respondents the quality of working conditions of 21 respondents was "Not at all influential", 37 respondents had "Slightly Influential" salary, 112 respondents had "Moderately Influential" salary, 247 respondents has "Very Influential" salary and 129 respondents had "Extremely Influential" salary with a percentage of 3.8\%, 6.8\%, 20.5\%, 45.2\% and 23.6\% making it cumulative of $100.0 \%$.

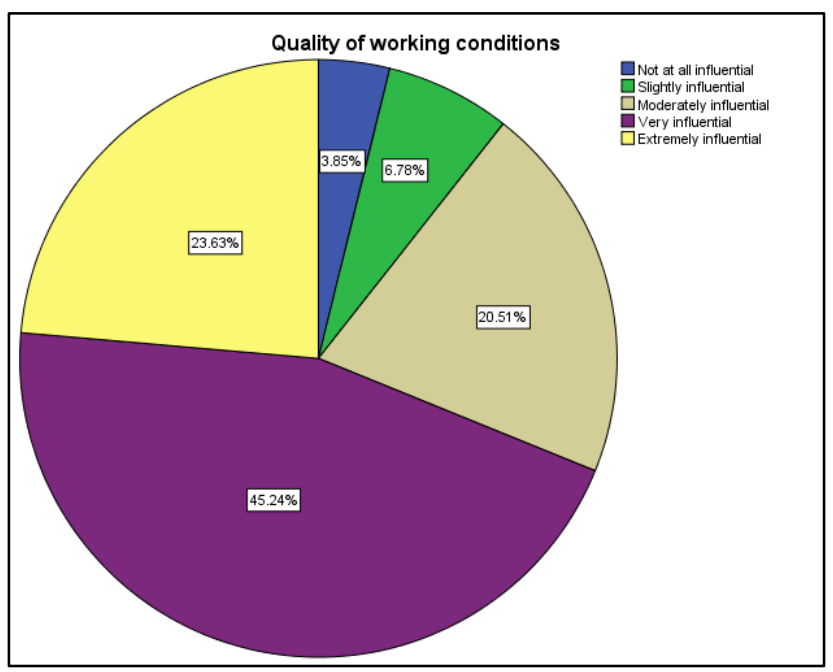




\subsection{Retirement Plan}

Table 10 Retirement plan of Respondents

\begin{tabular}{|l|l|l|l|l|}
\hline & Frequency & Percent & Valid Percent & Cumulative Percent \\
\hline Not at all influential & 16 & 2.9 & 2.9 & 2.9 \\
\hline Slightly influential & 40 & 7.3 & 7.3 & 10.3 \\
\hline Moderately influential & 91 & 16.7 & 16.7 & 26.9 \\
\hline Very influential & 226 & 41.4 & 41.4 & 68.3 \\
\hline Extremely influential & 173 & 31.7 & 31.7 & 100.0 \\
\hline Total & $\mathbf{5 4 6}$ & $\mathbf{1 0 0 . 0}$ & $\mathbf{1 0 0 . 0}$ & \\
\hline
\end{tabular}

Table 10 explains that out of total 546 respondents the retirement plan of 16 respondents was "Not at all influential", 40 respondents had "Slightly Influential" salary, 91 respondents had "Moderately Influential" salary, 226 respondents has "Very Influential" salary and 173 respondents had "Extremely Influential" salary with a percentage of $2.9 \%, 7.3 \%, 16.7 \%, 41.4 \%$ and $31.7 \%$ making it cumulative of $100.0 \%$.

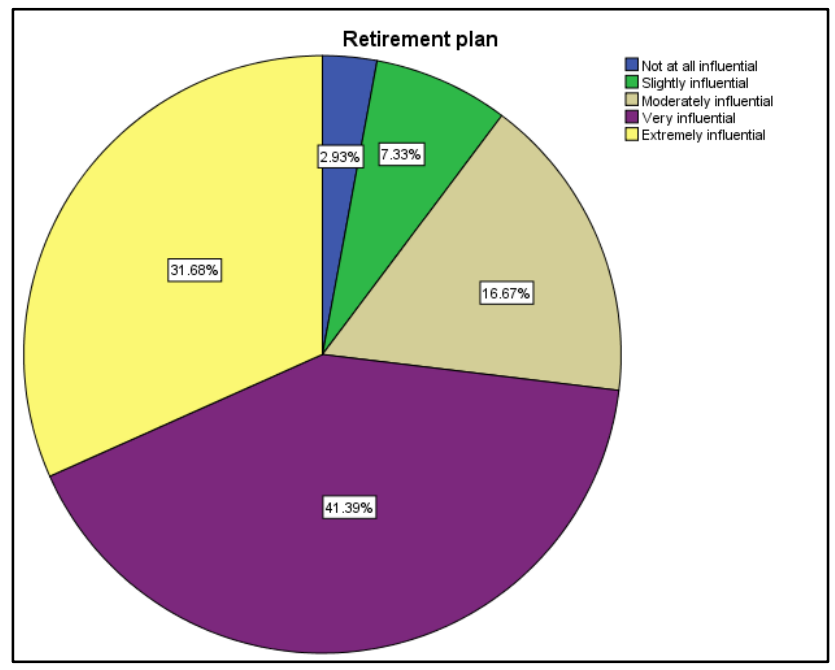

\subsection{Status as Employer or Owner}

Table 11 Status of Respondents

\begin{tabular}{|l|l|l|l|l|}
\hline & Frequency & Percent & Valid Percent & Cumulative Percent \\
\hline Not at all influential & 16 & 2.9 & 2.9 & 2.9 \\
\hline Slightly influential & 44 & 8.1 & 8.1 & 11.0 \\
\hline Moderately influential & 106 & 19.4 & 19.4 & 30.4 \\
\hline Very influential & 231 & 42.3 & 42.3 & 72.7 \\
\hline Extremely influential & 149 & 27.3 & 27.3 & 100.0 \\
\hline Total & $\mathbf{5 4 6}$ & $\mathbf{1 0 0 . 0}$ & $\mathbf{1 0 0 . 0}$ & \\
\hline
\end{tabular}

Table 11.0 explains that out of total 546 respondents the status as owners of 16 respondents was "Not at all influential", 40 respondents had "Slightly Influential" salary, 91 respondents had "Moderately Influential" salary, 226 respondents has "Very Influential" salary and 173 respondents had "Extremely Influential" salary with a percentage of $2.9 \%, 7.3 \%, 16.7 \%, 41.4 \%$ and $31.7 \%$ making it cumulative of $100.0 \%$. 


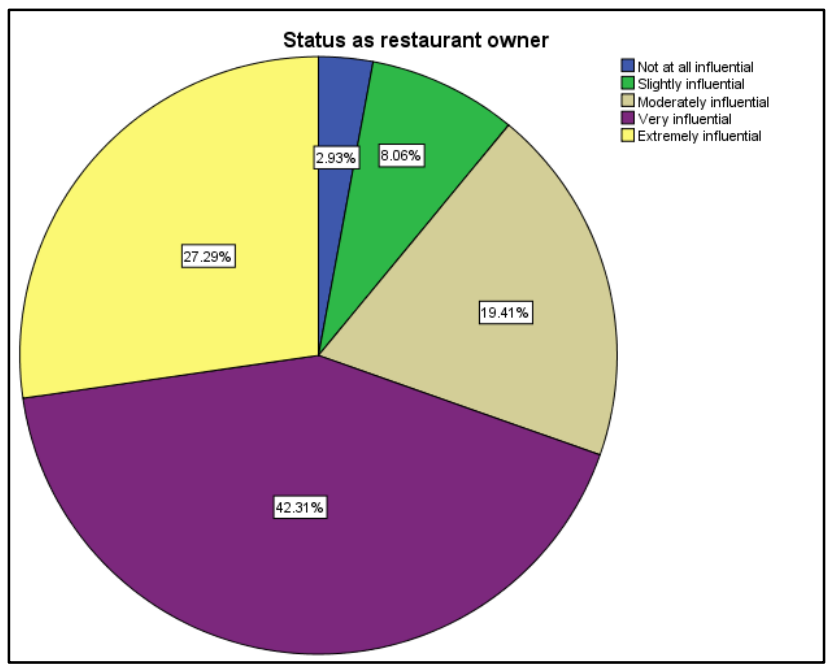

\subsection{Stock Options}

Table 12 Stock option of Respondents

\begin{tabular}{|l|l|l|l|l|}
\hline & Frequency & Percent & Valid Percent & Cumulative Percent \\
\hline Not at all influential & 17 & 3.1 & 3.1 & 3.1 \\
\hline Slightly influential & 51 & 9.3 & 9.3 & 12.5 \\
\hline Moderately influential & 110 & 20.1 & 20.1 & 32.6 \\
\hline Very influential & 236 & 43.2 & 43.2 & 75.8 \\
\hline Extremely influential & 132 & 24.2 & 24.2 & 100.0 \\
\hline Total & $\mathbf{5 4 6}$ & $\mathbf{1 0 0 . 0}$ & $\mathbf{1 0 0 . 0}$ & \\
\hline
\end{tabular}

Table 12 explains that out of total 546 respondents the stock options of 17 respondents was "Not at all influential", 51 respondents had "Slightly Influential" salary, 110 respondents had "Moderately Influential" salary, 236 respondents has "Very Influential" salary and 132 respondents had "Extremely Influential" salary with a percentage of $3.1 \%, 9.3 \%, 20.1 \%, 43.2 \%$ and $24.2 \%$ making it cumulative of $100.0 \%$.

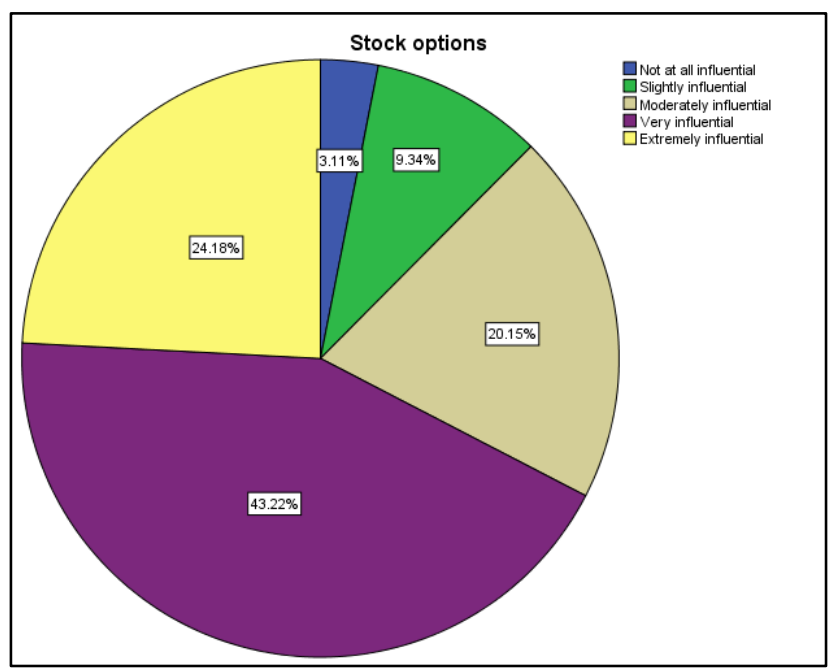




\subsection{Vacation /paid time off}

Table 13 Paid Time of Respondents

\begin{tabular}{|l|l|l|l|l|}
\hline & Frequency & Percent & Valid Percent & Cumulative Percent \\
\hline Not at all influential & 27 & 4.9 & 4.9 & 4.9 \\
\hline Slightly influential & 35 & 6.4 & 6.4 & 11.4 \\
\hline Moderately influential & 141 & 25.8 & 25.8 & 37.2 \\
\hline Very influential & 218 & 39.9 & 39.9 & 77.1 \\
\hline Extremely influential & 125 & 22.9 & 22.9 & 100.0 \\
\hline Total & $\mathbf{5 4 6}$ & $\mathbf{1 0 0 . 0}$ & $\mathbf{1 0 0 . 0}$ & \\
\hline
\end{tabular}

Table 13 explains that out of total 546 respondents the vacation or paid time of 27 respondents was "Not at all influential", 35 respondents had "Slightly Influential" salary, 141 respondents had "Moderately Influential" salary, 218 respondents has "Very Influential" salary and 125 respondents had "Extremely Influential" salary with a percentage of $4.9 \%, 6.4 \%, 25.8 \%, 39.9 \%$ and $22.9 \%$ making it cumulative of $100.0 \%$.

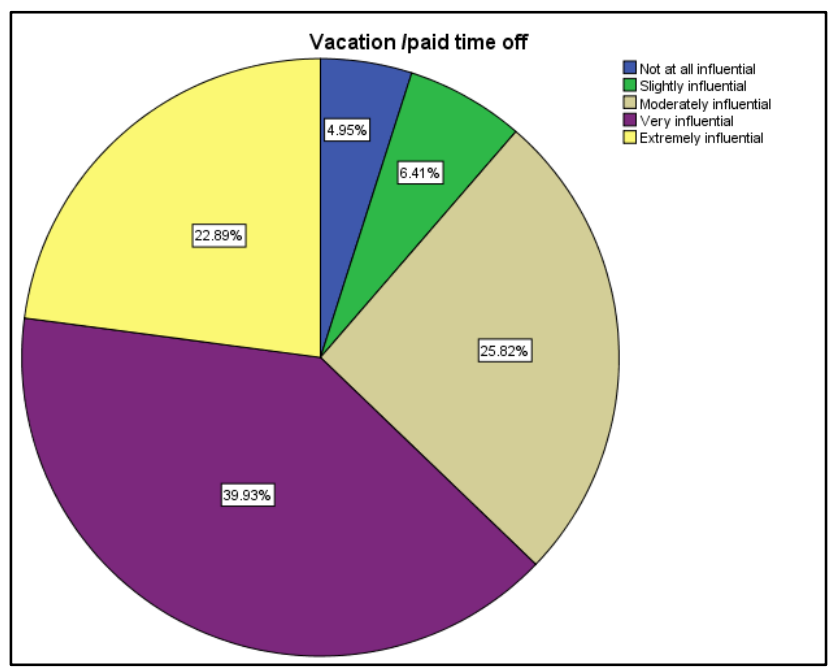

\subsection{Job Title of Respondents}

Table 14 Job Title of Respondents

\begin{tabular}{|l|l|l|l|l|}
\hline & Frequency & Percent & Valid Percent & Cumulative Percent \\
\hline Lecturer & 80 & 14.7 & 14.7 & 14.7 \\
\hline Assistant Professor & 228 & 41.8 & 41.8 & 56.4 \\
\hline Associate Professor & 214 & 39.2 & 39.2 & 95.6 \\
\hline Professor & 24 & 4.4 & 4.4 & 100.0 \\
\hline Total & $\mathbf{5 4 6}$ & $\mathbf{1 0 0 . 0}$ & $\mathbf{1 0 0 . 0}$ & \\
\hline
\end{tabular}

Table 14 explains that out of total 546 respondents the job title of 80 respondents was "Lecturer", 228 respondents were "Assistant Professor" salary, 214 respondents were "Associate Professor" salary and 24 respondents were "Professor" with a percentage of $14.7 \%, 41.8 \%, 39.2 \%$ and $4.4 \%$ making it cumulative of $100.0 \%$. 




\subsection{Marital Status}

Table 15 Marital Status of Respondents

\begin{tabular}{|l|l|l|l|l|}
\hline & Frequency & Percent & Valid Percent & Cumulative Percent \\
\hline Single & 313 & 57.3 & 57.3 & 57.3 \\
\hline Married & 233 & 42.7 & 42.7 & 100.0 \\
\hline Total & $\mathbf{5 4 6}$ & $\mathbf{1 0 0 . 0}$ & $\mathbf{1 0 0 . 0}$ & \\
\hline
\end{tabular}

Table 15.0 explains the marital status of respondents that out of total 546 respondents, 313 were "Single" and 233 respondents were "Married" with a percentage of $57.3 \%$, and $42.7 \%$ making it cumulative of $100.0 \%$.

\subsection{Total Experience}

Table 16 Experience of Respondents

\begin{tabular}{|l|l|l|l|l|}
\hline & Frequency & Percent & Valid Percent & Cumulative Percent \\
\hline 1-5 Years & 361 & 66.1 & 66.1 & 66.1 \\
\hline 6-10 Years & 125 & 22.9 & 22.9 & 89.0 \\
\hline 11-15 Years & 42 & 7.7 & 7.7 & 96.7 \\
\hline 16-20 Years & 12 & 2.2 & 2.2 & 98.9 \\
\hline 21-25 Years & 6 & 1.1 & 1.1 & 100.0 \\
\hline Total & $\mathbf{5 4 6}$ & $\mathbf{1 0 0 . 0}$ & $\mathbf{1 0 0 . 0}$ & \\
\hline
\end{tabular}

Table 16 explains the total experience of respondents that out of total 546 respondents, 361 had experience of 1-5 years, 125 respondents have experience of 6-10 years, 42 respondents had experience of 11-15 years, 12 respondents had experience of 16-20 years and 6 respondents had experiences of 2125 years respectively with percentage of $66.1 \%, 22.9 \%, 7.7 \%, 2.2 \%$ and $1.1 \%$ making it cumulative of $100.0 \%$. 


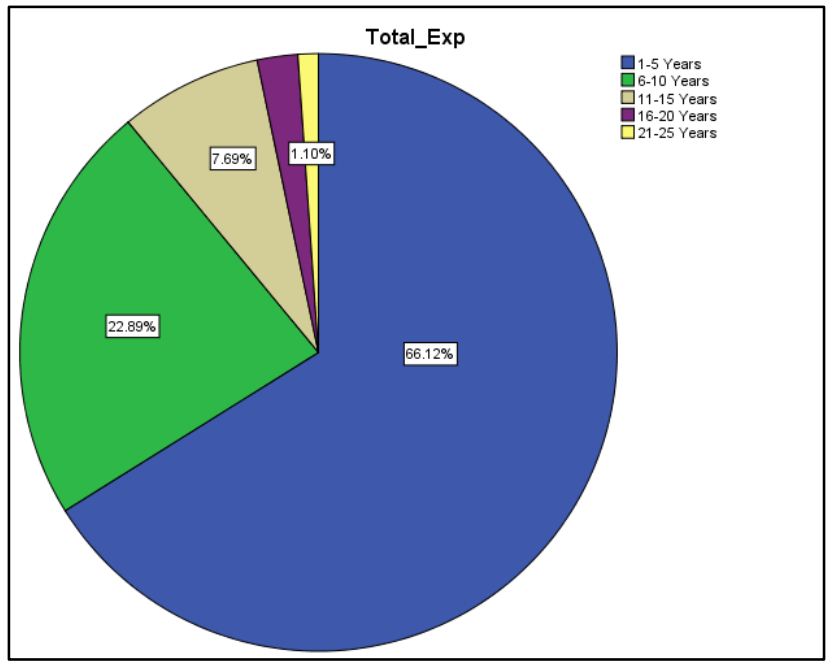

\subsection{Age}

Table 17 Age of Respondents

\begin{tabular}{|l|l|l|l|l|}
\hline & Frequency & Percent & Valid Percent & Cumulative Percent \\
\hline $\mathbf{2 1 - 3 0}$ Years & 390 & 71.4 & 71.4 & 71.4 \\
\hline 31-40 Years & 120 & 22.0 & 22.0 & 93.4 \\
\hline 41-50 Years & 28 & 5.1 & 5.1 & 98.5 \\
\hline 51-60 Years & 8 & 1.5 & 1.5 & 100.0 \\
\hline Total & $\mathbf{5 4 6}$ & $\mathbf{1 0 0 . 0}$ & $\mathbf{1 0 0 . 0}$ & \\
\hline
\end{tabular}

Table 17 explains the age of respondents that out of total 546 respondents, 390 respondents belonged to 21-30 years of age, 120 respondents belonged to 31-40 years of age, 28 respondents belonged to 41-50 years of age and 8 respondents belonged to 51-60 years of age respectively with percentages of $71.4 \%$, $22.0 \%, 5.1 \%$ and $1.5 \%$ making it cumulative of $100.0 \%$.

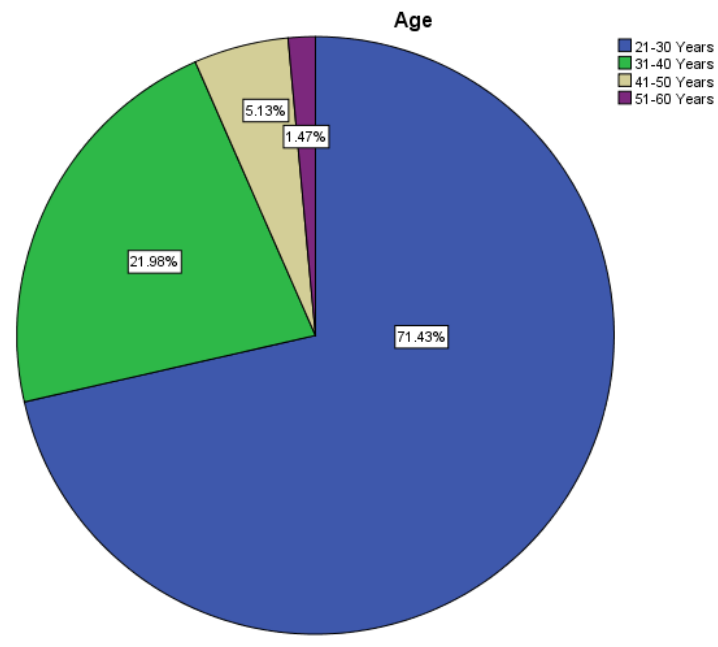

\subsection{Nature of Employment}

Table 18 Nature of Employment of Respondents

\begin{tabular}{|l|l|l|l|l|}
\hline & Frequency & Percent & Valid Percent & Cumulative Percent \\
\hline Regular & 405 & 74.2 & 74.2 & 74.2 \\
\hline Contractual & 141 & 25.8 & 25.8 & 100.0 \\
\hline Total & $\mathbf{5 4 6}$ & $\mathbf{1 0 0 . 0}$ & $\mathbf{1 0 0 . 0}$ & \\
\hline
\end{tabular}

Table 18 explains the nature of employment of respondents that out of total 546 respondents, 405 were 
"Regular" and 141 respondents were "Contractual" with a percentage of $74.2 \%$, and 25.8\% making it cumulative of $100.0 \%$.

\subsection{Education of Respondents}

Table 19 Education of Respondents

\begin{tabular}{|l|l|l|l|l|}
\hline & Frequency & Percent & Valid Percent & Cumulative Percent \\
\hline Masters/MPhil & 245 & 44.9 & 44.9 & 44.9 \\
\hline Doctorate & 263 & 48.2 & 48.2 & 93.0 \\
\hline Others & 38 & 7.0 & 7.0 & 100.0 \\
\hline Total & $\mathbf{5 4 6}$ & $\mathbf{1 0 0 . 0}$ & $\mathbf{1 0 0 . 0}$ & \\
\hline
\end{tabular}

Table 19 explains the education of respondents that out of total 546 respondents, 245 were "Master/MPhil qualified", 263 were Doctorate and 38 respondents had other qualification with a percentage of $44.9 \%$, and $48.2 \%$ and $7.0 \%$ making it cumulative of $100.0 \%$.

\subsection{Salary of Respondents}

Table 20 Education of Respondents

\begin{tabular}{|l|l|l|l|l|}
\hline & Frequency & Percent & Valid Percent & Cumulative Percent \\
\hline $\mathbf{2 0 0 0 0 - 4 0 0 0 0}$ & 90 & 16.5 & 16.5 & 16.5 \\
\hline $\mathbf{4 1 0 0 0 - 6 0 0 0 0}$ & 135 & 24.7 & 24.7 & 41.2 \\
\hline $\mathbf{6 1 0 0 0 - 9 0 0 0 0}$ & 120 & 22.0 & 22.0 & 63.2 \\
\hline $\mathbf{9 1 0 0 0 - 1 1 0 0 0 0}$ & 150 & 27.5 & 27.5 & 90.7 \\
\hline $\mathbf{1 1 0 0 0 0 - 1 3 0 0 0 0}$ & 51 & 9.3 & 9.3 & 100.0 \\
\hline Total & $\mathbf{5 4 6}$ & $\mathbf{1 0 0 . 0}$ & $\mathbf{1 0 0 . 0}$ & \\
\hline
\end{tabular}

Table 20 explains the experience of respondents that out of total 546 respondents, 90 had salary of 20,000 to $40,000,135$ had salary of 41,000-60,000, 120 had salary of 61,000-90,000, 150 had salary of $91,000-110,000$ amd51 had salary of $110,000-130,000$ with a percentage of $16.5 \%, 24.7 \%, 22.0 \%$, $27.5 \%$ and $9.3 \%$ making it cumulative of $100.0 \%$.



\subsection{Job Status of Respondents}

Table 21 Job Status of Respondents

\begin{tabular}{|l|l|l|l|l|}
\hline & Frequency & Percent & Valid Percent & Cumulative Percent \\
\hline Top Management & 15 & 2.7 & 2.7 & 2.7 \\
\hline Middle Management & 162 & 29.7 & 29.7 & 32.4 \\
\hline Lower Management & 154 & 28.2 & 28.2 & 60.6 \\
\hline Non-Managerial & 215 & 39.4 & 39.4 & 100.0 \\
\hline
\end{tabular}




\begin{tabular}{|l|l|l|l|}
\hline Total & 546 & 100.0 & 100.0 \\
\hline
\end{tabular}

Table 21 explains the job status of respondents that out of total 546 respondents, 12 belongs to top management, 162 belongs to middle management, 154 belongs to lower management and 215 belongs to non-managerial job with a percentage of $2.7 \%, 29.7 \%, 28.2 \%$ and $39.4 \%$ making it cumulative of $100.0 \%$.



Following table describes descriptive statistics including mean standard deviation, skewness and kurtosis. We can see that the retirement plan has the highest mean value, 3.92 while deferred compensation has the lowest mean value 2.99. All the standard deviations are approximately one. Skewness and kurtosis is within the threshold range.

\subsection{Descriptive Analysis}

\begin{tabular}{|c|c|c|c|c|c|c|c|c|c|}
\hline & \multirow[t]{2}{*}{$\mathbf{N}$} & \multirow[t]{2}{*}{ Min } & \multirow[t]{2}{*}{ Max } & \multirow[t]{2}{*}{ Mean } & \multirow{2}{*}{$\begin{array}{l}\text { Std. } \\
\text { Deviation }\end{array}$} & \multicolumn{2}{|l|}{ Skewness } & \multicolumn{2}{|l|}{ Kurtosis } \\
\hline & & & & & & Statistics & $\begin{array}{l}\text { Std. } \\
\text { Error }\end{array}$ & Statistics & $\begin{array}{l}\text { Std. } \\
\text { Error }\end{array}$ \\
\hline Base salary & 546 & 1 & 5 & 3.56 & 1.172 & -.568 & .105 & -.451 & .209 \\
\hline $\begin{array}{l}\text { Community association/ } \\
\text { location }\end{array}$ & 546 & 1 & 5 & 3.43 & 1.140 & -.493 & .105 & -.512 & .209 \\
\hline Deferred compensation/ & 546 & 1 & 5 & 2.99 & 1.174 & .004 & .105 & -.946 & .209 \\
\hline Job Autonomy & 546 & 1 & 5 & 3.49 & 1.081 & -.634 & .105 & -.238 & .209 \\
\hline Job responsibility & 546 & 1 & 5 & 3.53 & 1.210 & -.592 & .105 & -.559 & .209 \\
\hline Medical, dental, life insurance & 546 & 1 & 5 & 3.58 & 1.075 & -.587 & .105 & -.207 & .209 \\
\hline $\begin{array}{l}\text { Ownership stake/ equity } \\
\text { interest }\end{array}$ & 546 & 1 & 5 & 3.42 & 1.085 & -.507 & .105 & -.219 & .209 \\
\hline Performance bonus & 546 & 1 & 5 & 3.41 & 1.097 & -.414 & .105 & -.552 & .209 \\
\hline Quality of working conditions & 546 & 1 & 5 & 3.78 & 1.006 & -.862 & .105 & .522 & .209 \\
\hline Retirement plan & 546 & 1 & 5 & 3.92 & 1.017 & -.922 & .105 & .444 & .209 \\
\hline Status as employer or owner & 546 & 1 & 5 & 3.83 & 1.013 & -.802 & .105 & .242 & .209 \\
\hline Stock options & 546 & 1 & 5 & 3.76 & 1.020 & -.743 & .105 & .106 & .209 \\
\hline Vacation /paid time off & 546 & 1 & 5 & 3.69 & 1.047 & -.738 & .105 & .234 & .209 \\
\hline Job Title & 546 & 1 & 4 & 2.33 & .777 & -.092 & .105 & -.562 & .209 \\
\hline Marital Status & 546 & 1 & 2 & 1.43 & .495 & .297 & .105 & -1.919 & .209 \\
\hline Total Experience & 546 & 1 & 5 & 1.49 & .818 & 1.903 & .105 & 3.739 & .209 \\
\hline Age & 546 & 1 & 4 & 1.37 & .651 & 1.869 & .105 & 3.304 & .209 \\
\hline Nature of Employment & 546 & 1 & 2 & 1.26 & .438 & 1.108 & .105 & -.776 & .209 \\
\hline Education & 546 & 1 & 3 & 1.62 & .613 & .444 & .105 & -.655 & .209 \\
\hline Salary & 546 & 1 & 5 & 2.88 & 1.243 & -.005 & .105 & -1.094 & .209 \\
\hline Job Status & 546 & 1 & 4 & 3.04 & .894 & -.314 & .105 & -1.182 & .209 \\
\hline
\end{tabular}


The following table is about Analysis of variance that describes mean differences among variables and their relative significance. We can observe that there is no significant difference except for job autonomy and retirement plan.

\subsection{ANOVA}

\begin{tabular}{|c|c|c|c|c|c|c|}
\hline & & $\begin{array}{l}\text { Sum of } \\
\text { Squares }\end{array}$ & DF & $\begin{array}{l}\text { Mean } \\
\text { Square } \\
\end{array}$ & $\mathbf{F}$ & Sig \\
\hline \multirow{3}{*}{ Base salary } & Between Groups & 1.560 & 3 & .520 & .377 & .769 \\
\hline & Within Groups & 746.945 & 542 & 1.378 & & \\
\hline & Total & 748.505 & 545 & & & \\
\hline \multirow[t]{3}{*}{ Community association } & Between Groups & 5.205 & 3 & 1.735 & 1.338 & .261 \\
\hline & Within Groups & 702.787 & 542 & 1.297 & & \\
\hline & Total & 707.993 & 545 & & & \\
\hline \multirow[t]{3}{*}{ Deferred compensation } & Between Groups & 3.120 & 3 & 1.040 & .754 & .521 \\
\hline & Within Groups & 747.835 & 542 & 1.380 & & \\
\hline & Total & 750.954 & 545 & & & \\
\hline \multirow[t]{3}{*}{ Job Autonomy } & Between Groups & 10.077 & 3 & 3.359 & 2.906 & .034 \\
\hline & Within Groups & 626.407 & 542 & 1.156 & & \\
\hline & Total & 636.484 & 545 & & & \\
\hline \multirow[t]{3}{*}{ Job responsibility } & Between Groups & 6.763 & 3 & 2.254 & 1.544 & .202 \\
\hline & Within Groups & 791.143 & 542 & 1.460 & & \\
\hline & Total & 797.907 & 545 & & & \\
\hline \multirow{3}{*}{ Medical, life insurance } & Between Groups & 4.562 & 3 & 1.521 & 1.319 & .267 \\
\hline & Within Groups & 624.859 & 542 & 1.153 & & \\
\hline & Total & 629.421 & 545 & & & \\
\hline \multirow{3}{*}{ Ownership stake } & Between Groups & 6.183 & 3 & 2.061 & 1.758 & .154 \\
\hline & Within Groups & 635.239 & 542 & 1.172 & & \\
\hline & Total & 641.421 & 545 & & & \\
\hline \multirow[t]{3}{*}{ Performance bonus } & Between Groups & 1.757 & 3 & .586 & .485 & .693 \\
\hline & Within Groups & 654.345 & 542 & 1.207 & & \\
\hline & Total & 656.103 & 545 & & & \\
\hline \multirow[t]{3}{*}{ Quality of working conditions } & Between Groups & 7.169 & 3 & 2.390 & 2.379 & .069 \\
\hline & Within Groups & 544.458 & 542 & 1.005 & & \\
\hline & Total & 551.626 & 545 & & & \\
\hline \multirow[t]{3}{*}{ Retirement plan } & Between Groups & 10.726 & 3 & 3.575 & $\mathbf{3 . 5 0 2}$ & .015 \\
\hline & Within Groups & 553.399 & 542 & 1.021 & & \\
\hline & Total & 564.125 & 545 & & & \\
\hline \multirow[t]{3}{*}{ Status as employer or owner } & Between Groups & 6.699 & 3 & 2.233 & 2.191 & .088 \\
\hline & Within Groups & 552.460 & 542 & 1.019 & & \\
\hline & Total & 559.159 & 545 & & & \\
\hline \multirow[t]{3}{*}{ Stock options } & Between Groups & 7.313 & 3 & 2.438 & 2.358 & .071 \\
\hline & Within Groups & 560.257 & 542 & 1.034 & & \\
\hline & Total & 567.570 & 545 & & & \\
\hline \multirow[t]{3}{*}{ Vacation/paid time off } & Between Groups & 5.306 & 3 & 1.769 & 1.617 & .184 \\
\hline & Within Groups & 592.616 & 542 & 1.093 & & \\
\hline & Total & 597.921 & 545 & & & \\
\hline
\end{tabular}

The following table describes the bivariate relationship among various variables. Most of the relationships are strong and significantly correlated, except base salary with performance bonus, community association with performance bonus. Likewise performance bonus with status as employer or owner is also insignificant.

\subsection{Correlation among Variables}

\begin{tabular}{|l|l|l|l|l|l|l|l|l|l|l|l|l|l|}
\hline Variables & $\mathbf{( 1 )}$ & $\mathbf{( 2 )}$ & $\mathbf{( 3 )}$ & $\mathbf{( 4 )}$ & $\mathbf{( 5 )}$ & $\mathbf{( 6 )}$ & $\mathbf{( 7 )}$ & $\mathbf{( 8 )}$ & $\mathbf{( 9 )}$ & $\mathbf{( 1 0 )}$ & $\mathbf{( 1 1 )}$ & $\mathbf{( 1 2 )}$ & $\mathbf{( 1 3}$ \\
\hline Base salary (1) & 1 & & & & & & & & & & & & \\
\hline
\end{tabular}




\begin{tabular}{|c|c|c|c|c|c|c|c|c|c|c|c|c|c|}
\hline $\begin{array}{l}\text { Community } \\
\text { association (2) }\end{array}$ & $.740 * *$ & 1 & & & & & & & & & & & \\
\hline $\begin{array}{l}\text { Deferred } \\
\text { compensation } \\
\text { (3) }\end{array}$ & $-132 * *$ & -.057 & 1 & & & & & & & & & & \\
\hline $\begin{array}{ll}\text { Job } & \text { Autonomy } \\
\text { (4) } & \end{array}$ & $.563 * *$ & $\begin{array}{l}.622 * \\
*\end{array}$ & -.005 & 1 & & & & & & & & & \\
\hline $\begin{array}{l}\text { Job } \\
\text { responsibility } \\
\text { (5) }\end{array}$ & $.550 * *$ & $\begin{array}{l}.588^{*} \\
*\end{array}$ & .003 & $\begin{array}{l}.62 \\
5 * *\end{array}$ & 1 & & & & & & & & \\
\hline $\begin{array}{l}\text { Medical, dental, } \\
\text { life insurance (6) }\end{array}$ & $.580 * *$ & $\begin{array}{l}.618^{*} \\
*\end{array}$ & -.042 & $\begin{array}{l}.60 \\
5^{* *}\end{array}$ & $\begin{array}{l}.722 * \\
*\end{array}$ & 1 & & & & & & & \\
\hline $\begin{array}{l}\text { Ownership } \\
\text { stake/ equity } \\
\text { interest (7) }\end{array}$ & $.463 * *$ & $\begin{array}{l}.482 * \\
*\end{array}$ & -.014 & $\begin{array}{l}.50 \\
4 * *\end{array}$ & $\begin{array}{l}.565 * \\
*\end{array}$ & $\begin{array}{l}.549 * \\
*\end{array}$ & 1 & & & & & & \\
\hline $\begin{array}{l}\text { Performance } \\
\text { bonus }(8)\end{array}$ & .075 & .063 & $\begin{array}{l}.313^{*} \\
*\end{array}$ & $\begin{array}{l}.06 \\
7\end{array}$ & .063 & $.094 *$ & $\begin{array}{l}.330 * \\
*\end{array}$ & 1 & & & & & \\
\hline $\begin{array}{ll}\text { Quality } & \text { of } \\
\text { working } & \\
\text { conditions (9) }\end{array}$ & $.475^{* *}$ & $\begin{array}{l}.424 * \\
*\end{array}$ & $\begin{array}{l}- \\
.182 *\end{array}$ & $\begin{array}{l}.32 \\
1 * *\end{array}$ & $\begin{array}{l}.422 * \\
*\end{array}$ & $\begin{array}{l}.407 * \\
*\end{array}$ & $\begin{array}{l}- \\
.174 * \\
*\end{array}$ & $\begin{array}{l}.330 * \\
*\end{array}$ & 1 & & & & \\
\hline $\begin{array}{l}\text { Retirement plan } \\
\text { (10) }\end{array}$ & $.398^{* *}$ & $\begin{array}{l}.405^{*} \\
*\end{array}$ & $\begin{array}{l}- \\
*\end{array}$ & $\begin{array}{l}.33 \\
0^{* *}\end{array}$ & $\begin{array}{l}.406^{*} \\
*\end{array}$ & $\begin{array}{l}.410^{*} \\
*\end{array}$ & $\begin{array}{l}.394 * \\
*\end{array}$ & $\begin{array}{l}- \\
.136 *\end{array}$ & $\begin{array}{l}.406^{*} \\
*\end{array}$ & 1 & & & \\
\hline $\begin{array}{ll}\text { Status } & \text { as } \\
\text { employer } & \text { or } \\
\text { owner (11) } & \end{array}$ & $.486^{* *}$ & $\begin{array}{l}.394 * \\
*\end{array}$ & $\begin{array}{l}- \\
.136 *\end{array}$ & $\begin{array}{l}.40 \\
6^{* *}\end{array}$ & $\begin{array}{l}.474 * \\
*\end{array}$ & $\begin{array}{l}.439 * \\
*\end{array}$ & $\begin{array}{l}.482 * \\
*\end{array}$ & -.014 & $\begin{array}{l}.504 * \\
*\end{array}$ & $\begin{array}{l}.565 \\
* *\end{array}$ & 1 & & \\
\hline $\begin{array}{l}\text { Stock options } \\
\text { (12) }\end{array}$ & $.433 * *$ & $\begin{array}{l}.451^{*} \\
*\end{array}$ & $\begin{array}{l}- \\
*\end{array}$ & $\begin{array}{l}.44 \\
6^{* * *}\end{array}$ & $\begin{array}{l}.454 * \\
*\end{array}$ & $\begin{array}{l}.452 * \\
*\end{array}$ & $\begin{array}{l}.433 * \\
*\end{array}$ & $\begin{array}{l}.451 * \\
*\end{array}$ & $\begin{array}{l}- \\
*\end{array}$ & $\begin{array}{l}.446 \\
* *\end{array}$ & $\begin{array}{l}.454 * \\
*\end{array}$ & 1 & \\
\hline $\begin{array}{l}\text { Vacation /paid } \\
\text { time off (13) }\end{array}$ & $.451 * *$ & $\begin{array}{l}.424 * \\
*\end{array}$ & $\begin{array}{l}- \\
.113 *\end{array}$ & $\begin{array}{l}.45 \\
6^{* *}\end{array}$ & $\begin{array}{l}.417 * \\
*\end{array}$ & $\begin{array}{l}.442 * \\
*\end{array}$ & $\begin{array}{l}. \\
.174 * \\
*\end{array}$ & $\begin{array}{l}.330 * \\
*\end{array}$ & $\begin{array}{l}.406 * \\
*\end{array}$ & $\begin{array}{l}.410 \\
* *\end{array}$ & $\begin{array}{l}.394 * \\
*\end{array}$ & $\begin{array}{l}- \\
.136 *\end{array}$ & 1 \\
\hline
\end{tabular}

\section{Conclusion}

Basic purpose of this research was to find out how different compensation offerings affect different level of educational managers in Punjab in different universities, public as well as private sector. Specifically in this study, Base salary ,Community association/ location, Deferred compensation, Job Independence, Job obligation, Medicinal, dental, Performance bonus, Ownership stake/ equity interest, life insurance, Quality of working environments, Withdrawal plan , Position as employer or possessor, Stock choices , Holiday /salaried time off, Job Title, Marital Status, Total Experience, Age, Nature of Employment, Education, Salary and Job Status were considered as compensation which are widely used in various educational institutions.

The retirement plan has the highest mean value, 3.92 while deferred compensation has the lowest mean value 2.99. All the standard deviations are approximately one. Skewness and kurtosis is within the threshold range. The mean differences among variables and their relative significance was computed. There is no significant difference except for job autonomy and retirement plan. The bivariate relationships among various variables show that most of the relationships are strong and significant, except base salary with performance bonus, community association with performance bonus. Likewise, performance bonus with status as employer or owner is also insignificant.

However, this study is an initial step towards the attractiveness of compensation among educational managers. The longitudinal research can be conducted to find whether over the period, preferences of employees change or not. Moreover, the data was limited to Punjab based educational institutions and more data can be collected from whole Pakistan to make it more generalize. The policy makers must focus on job autonomy and retirements plans to motivate employees, specifically with greater job 
experience and higher-level designations.

\section{Limitations and Future Guidelines}

This study is not free of limitations like other studies. The nature of the study is cross sectional while the choice of employees may change over a period. So, longitudinal study may produce different results. As the sample drawn was related to a developing country, sample from developed countries may differ in the choice of compensation offerings due to different economic conditions and cultural choices. Its generalizability may also be increased. It is recommended that future research should emphasis on the role of age, gender and culture in the compensation offerings. Executive compensation should be considered separately from general offerings. Moreover, pay for performance can be used as moderating or contingent effect to see the patterns more clearly.

\section{References}

Dibble, Suzanne, (1999), Keeping Your Valuable Employees, New York, Wiley.

Ermel, Lauren \& Bohl, Don, (1997), Responding to a Tight Labor Market: Using Incentives to Attract and Retain Workers, Compensation and Benefits review, America Management Association International, 29 (6).

Lawler, Edward E., (1981), Determining Total Compensation: Strategic Issues, Pay and Organization Development, Reading, MA. Addison-Wesley.

Lawler, Edward E., (1987), The Design of Effective Reward Systems, Englewood Cliffs, NJ, Prentice Hall.

Lazear, Edward, (1999) Personnel Economics: Past Lessons and Future Directions, Journal of Labor Economics, 17 (2).

Mcfillen, James, Riegel, Carl \& Enz, Cathy, (1986, Nov.), Why restaurant managers Qui (and how to keep them), The Cornell Hotel and Restaurant Administration Quarterly.

Mobley, William H., (1982), Employee Turnover: Causes, Consequences, and Control Reading, MA., Addison-Wesley.

Muller, Christopher, C., (1999), The Business of Restaurants: 2001 and Beyond, Hospitality Management, 18 (4).

Roseman, Edward, (1981), Managing Employee Turnover: A Positive Approach, New York, AMACOM.

Steers, Richard, M., \& Porter, Lyman, (1991) Motivation and Work Behavior, New York, McGraw Hill.

Wasmuth, William J. \& Davis, Stanley W., (1983, May), Managing Employee Turnover: Why Employees Leave, The Cornell Hotel and Restaurant Administration Quarterly.

Woods, Robert H., (1999), Predicting is Difficult, Especially About the Future: Human Resources in the New Millenium, Hospitality Management, 18 (4). 